\title{
Amazônia e Sucam
}

Mario B. Aragão*

Amazônia: planetarização e moratória ecológica. Samuel Benchimol. São Paulo, CERED, 144p.
*Pesquisador Titular da Escola Nacional de Saúde Públical Fio. cruz
Abre o livro um comentátio sobre "Os limites do crescimento" de Dennis Meadows, publicado em 1971, e que tanta celeuma provocou. Eu mesmo fiquei revoltado com a solução proposta para o mundo. Quem estava desenvolvido ficava desenvolvido e quem estava atrasado continuava atrasado. Se essa proposta poderia ser implementada, nunca se poderá saber. Entretanto, passados quase vinte anos, a situação do mundo é muito pior. Os países ricos estão mais ricos e os pobres mais pobres. O que entre nós se verifica dentro do próprio país.

Não concordamos com a proposta do aucor da criação de um fundo a ser gerido pela ONU para a preservação da natureza da Amazônia. Uma agência da ONU, a Organização Mundial da Saúde, já nos tem dado bastante prejuízo.

Dois capítulos mostram que a queima da floresta amazônica pouco tem a ver com o aumento do gás carbônico na atmosfera. É bom saber isso mas, há outro problema pior. Qual o benefício que o país tem tido com a queima da floresta? Um grande prejuízo, unicamente para que alguns ricos ganhem muito dinheiro com a valorização das terras, que lhes são conce didas ou vendidas a preço baixo. Já está mais que sabido que a pecuária nâo é auto-sustentável nesses pastos formados nas áreas florestais. Além disso, apenas a extração de borracha e a coleta de castanha dão maior rendimento do que esses bois. Sobre esse assunto o autor tem uma expressão muito adequada: "enriquecer antes que acabe".

Quando passa a tratar da Sucam, da Zona Franca de Manaus, das rodovias e das hidroelétricas, o livro entra numa grande confusão. Vem depois uma chamada moratória ecológia, que para mim não faz sentido.

Um capítulo com o título "O quadro ecológico" reúne opiniões de vários pesquisadores que trabalharam na Amazônia. No conjunto está confuso, mas nele destaca-se, pela lucidez, o que foi dito pelo botânico Ghillean Prance.

O livro termina com uma longa série de quadros estatísticos, onde vale a pena mencionar dois comentários do autor. No relativo à produção de ouro, diz que ela ocupa cerca de 700.000 pessoas e que, das 100 toneladas/ano produzidas, $50 \%$ são desviadas para o mercado paralelo e informal (leia-se contrabando). Sobre a exportação de peixes ornarnentais, que não é pequena, pois certa ve $z$ vi diversos barcos abarrota-

Cadernos de Saúde Pública, RJ, 6(1): 94-96 jan/mar, 1990 
dos no rio Negro, informa que, em Hong Kong e na China, já estão conseguindo a reprodução de alguns desses poixes, o que já eliminou essa exportação pela Colômbia.

Em suma, um livro bem começado e mal terminado. $\mathrm{O}$ autor tem mestrado nos Estados Unidos e doutorado na Faculdade de Direito do Amazonas mas, no que escreve, nota-se falta de preparo básico. Seria muito melhor que o governo, em vez de estar gastando fortunas com pós-graduação, procurasse melhorar os cursos de graduação.

Muito útil a publicação do 2\% volume de "Sucan. Sua origem, sua história" que o nosso amigo dos tempos do DNERu, Sr. Hélbio, acaba de nos remeter.

Logo no prefácio o Dr. Josélio Carvalho Branco lembra aos responsáveis pela Reforma Sanitária que não se deve ir com muita sede ao pote. A eliminação, pura e simples, da Sucam criaria problemas sérios para a rede básica de saúde. A volta da transmissão da dengue e, principalmente, da malária sobrecarregaria os postos de saúde. Ainda mais que, estudo feito em São Paulo e que está em publicação nos Cademos de Saúde Pública mostrou que a rede básica de saúde, mesmo num estado como São Paulo, nāo é eficiente na manutenção da erradiação da malária. Dentro dessa ordem de idéias é preciso lembrar que o guarda da Sucam é o único funcionário público que todo brasileiro conhece. Uma das coisas que mais nos impressionou, quando trabalhamos na Amazônia, foi encontrar lanchas com guardas da Sucam nos rios mais distantes. Logo na introdução, o livro de Hélbio conta o caso de uma equipe de guardas borrifadores que perderam a hélice da lancha num trecho completamente deserto. A solução foi trabalhar durante dois dias fazendo uma hélice de madeira, que permitiu alcançar um posto de rádio da Força Aérea Brasileira.

Seguem-se os cinco trabalhos premiados no concurso "A vida cotidiana de um guarda da Sucam". Tirando o de um amazonense que contou toda a sua vida em verso, os trabalhos não são bons. Trazem muitas queixas, próprias de funcionários públicos.

O mais não tem muito interesse. Meios de transporte e equipamentos utilizados, número de empregados em diversas atividades e ocupantes de cargos gratificados. Uma surpresa agradável foi ver citado, nessa parte, um estudo dos colegas Elsa R. Paim e A. C. Médici.

A companhando a preocupação atual com a Reforma Sanitária, estão transcritos diversos atos, a começar pela exposição de motivos $031 / 87$, dos ministros de Saúde e da Previdência, que é bastante complicada. Fala muito e diz pouco.

Cadernos de Saúde Pública, RJ, 6(1): 94-96 jan/mar, 1990
Sucam. Sua origem, sua história. Segundo volume. Hélbio Femandes Moraes. Brasília, Sucam, 1988, 268p. 
O relatório de um seminário da Sucam sobre o SUDS chama a atenção sobre a inadequação dos equipamentos de saúde existentes em alguns estados, e lembra que a Sucan deverá operar, com tecnologia própria, em situaçóes que requeiram atuação verticalizada.

Não sabíamos que um decreto de 1988 criou o Comando Sucam de Operaçōes Sanitárias de Emergência, assunto que nāo entendemos bem. Sempre vimos não só a Sucam, mas também os seus antecessores, como o DNERı e outros, atuarem com a maior eficiência nos momentos de calamidade pública. Não resta dúvida que, atualmente, a burocracia está complicadíssima, mas bastaria un decreto, liberando a Sucam das peias burocráticas, durante os períodos de calamidade.

Há decretos criando campanhas contra malária e Aedes aegypti, o que não entendemos, pois, ambas são obrigaçóes normais da Sucam. Acreditamos que dever-se-ia, aproveitando os ventos da Reforma Sanitária, passar as endemias de menor repercussão econômica para os estados ou municípios, como já foi feito com as verminoses intestinais. Até mais, como originários que somos de um serviço especializado, o de malária, e tendo visto a queda da eficiência desse serviço, à medida que foi recebendo o encargo de outras endemias, aproveitamos a oportunidade para sugerir que se deixe apenas a malária por conta da Sucam. No nosso entender o combate ao Aedes, que agora são dois: aegypti e albopictus, deveria passar a ser feito por um serviço novo. A esse respeito há um problema a resolver: vamos tentar novamente a erradiação ou vamos conviver com esses mosquitos, como fazem os Estados Unidos. Nessa última hipótese nos parece que o mais racional seria entregar as operaçōes de campo a empresas particulares, em vez de arregimentar um enorme corpo de funcionários. Isso, naturalmente, vai requerer um pequeno núcleo de pessoal de alto nível, não só para ditar as técnicas como para controlar o trabalho.

Em suma, se estamos tentando uma Reforma Sanitária, cada um deve dar a sua opinião e, por isso, deixamos aqui os nossos agradecimentos ao Sr. Hélbio, por essa oportunidade de dizer o que pensamos. 